Analisis Model Pengelolaan Zakat dan Wakaf

\title{
Analisis Model Pengelolaan Zakat dan Wakaf \\ (Studi Yayasan Yatim Mandiri Cabang Malang)
}

\author{
Nihayatu Aslamatis Solekah \\ Fakultas Ekonomi Universitas Islam Negeri (UIN) Maulana \\ Malik Ibrahim Malang
}

\begin{abstract}
Among the objectives of waqf in Islam is the distribution of welfare among the people and poverty eradication. When wellmanaged endowments will support the development both in economic, religious, social, cultural, political, defense and security. The purpose of this study was to examine the management model of zakat and waqf productive. The results of this study are expected to provide benefits to provide a more substantial to the scientists, researchers, readers and the public that there is a model of productive management of waqf grant that can be used as an example in the management of zakat and waqf productive. The results showed that the foundation is independent orphans have an independent organizational system, in which the form of institutions such as the Institute Amil Zakat generally resulting in organizational systems there is no interference from government regulations. Constraints / Problems experienced in Yayasan Yatim Mandiri Malang from the internal aspect is the lack of qualified Human Resources and Human Resource Capability less creative. Constraints / problems faced in the Orphan Foundation of Malang independent external aspeks is still modest community Thought Lack of support from family. To resolve the internal problems of orphans independent foundation that is to prepare a Qualified Human Resources (Internal). As for the external problem then it should maximize the marketing and provide understanding to families of orphans
\end{abstract}

Keywords : management, zakat, productive waqf

\section{PENDAHULUAN}

Wakaf diambil dari kata "waqafa", menurut bahasa berarti menahan atau berhenti. Dalam hukum Islam, wakaf berarti menyerahkan suatu hak milik yang tahan lama (zatnya) kepada seseorang atau nadzir (penjaga wakaf), baik berupa perorangan maupun badan pengelola dengan ketentuan bahwa hasil atau manfaatnya digunakan untuk hal-hal yang sesuai dengan syariat 
islam. Harta yang telah diwakafkan keluar dari hak milik yang mewakafkan dan bukan pula menjadi hak milik nazhir, tetapi menjadi hak milik Allah dalam pengertian hak masyarakat umum. (Sudarsono, 2008).

Wakaf juga sebagai usaha pembentukan watak kepribadian seorang muslim untuk melepaskan sebagian hartanya untuk kepentingan orang lain, juga merupakan investasi pembangunan yang bernilai tinggi tanpa memperhitungkan jangka waktu dan keuntungan materi bagi orang yang mewakafkan. Peranannya dalam pemerataan kesejahteraan di kalangan umat dan penanggulangan kemiskinan termasuk diantara sekian sasaran wakaf dalam ajaran Islam. Dengan demikian jika wakaf dikelola dengan baik tentu sangat menunjang pembangunan, baik di bidang ekonomi, agama, sosial budaya, politik maupun pertahanan keamanan. (Ismawati, 2007).

Namun dengan kurang nya pengetahuan masyarakat, terkadang mereka merancukan pengertian dari wakaf. Anggapan wakaf adalah sama dengan shadaqah/ hibah, hal ini perlu diluruskan, bahwa wakaf dan shadaqah/ hibah memiliki perbedaan. Sebagaimana disampaikan oleh Sudarsono (2008) perbedaannya sebagai berikut:

Tabel 1 Perbedaan Wakaf dengan Shodaqoh Atau Hibah

\begin{tabular}{|l|l|}
\hline \multicolumn{1}{|c|}{ Wakaf } & \multicolumn{1}{c|}{ Shodaqoh/Hibah } \\
\hline $\begin{array}{l}\text { Menyerahkan kepemilikan suatu } \\
\text { barang kepada orang lain }\end{array}$ & $\begin{array}{l}\text { Menyerahkan kepemilikan suatu } \\
\text { barang kepada pihak lain }\end{array}$ \\
\hline $\begin{array}{l}\text { Hak milik atas barang } \\
\text { dikembalikan } \\
\text { kepada Allah. }\end{array}$ & $\begin{array}{l}\text { Hak milik atas barang dikembalikan } \\
\text { kepada penerima shadaqah/ hibah }\end{array}$ \\
\hline $\begin{array}{l}\text { Objek wakaf tidak boleh diberikan } \\
\text { atau dijual kepada pihak lain }\end{array}$ & $\begin{array}{l}\text { Objek shadaqah/ hibah boleh } \\
\text { diberikan atau dijual kepada pihak } \\
\text { lain }\end{array}$ \\
\hline $\begin{array}{l}\text { Manfaat barang biasanya } \\
\text { dinikmati untuk kepentingan } \\
\text { sosial }\end{array}$ & $\begin{array}{l}\text { Manfaat barang dinikmati oleh } \\
\text { penerima shadaqah/ hibah }\end{array}$ \\
\hline $\begin{array}{l}\text { Objek wakaf biasanya kekal } \\
\text { zatnya. }\end{array}$ & $\begin{array}{l}\text { Objek shadaqah/ hibah tidak harus } \\
\text { kekal zatnya }\end{array}$ \\
\hline $\begin{array}{l}\text { Pengelolaan objek wakaf } \\
\text { diserahkan kepada administrator } \\
\text { yang disebut nazhir/mutawalli }\end{array}$ & $\begin{array}{l}\text { Pengelolaan objek shadaqah/ hibah } \\
\text { diserahkan kepada si penerima }\end{array}$ \\
\hline
\end{tabular}

Sumber : Karim Business Consulting, 2003 
Di Indonesia, wakaf lebih dikenal oleh masyarakat dalam bentuk tanah, namun pemerintah pun telah menetapkan wakaf uang sebagai terobosan wakaf yang dapat berkontribusi dalam membantu mengurangi tingkat kemiskinan dilndonesia. Wakaf uang ini telah diatur dalam Undang -Undang Republik Indonesia Nomor 41 Tahun 2004 Tentang Wakaf Uang, dan bahkan sebelum ditetapkan UU tersebut, Majelis Ulama Indonesia (MUI) telah mengeluarkan Keputusan Fatwa Tentang Wakaf Uang pada tahun 2002. (www.bwi.or.id).

Pengelolaan harta benda wakaf, sebagian besar masih bersifat tradisional sehingga manfaatnya belum dapat dirasakan. Banyak data yang menggambarkan betapa besarnya potensi wakaf. Kendati demikian, realitasnya masih jauh dari yang diharapkan, oleh karena itu, untuk peningkatan pengetahuan, pengadministrasian dengan baik. Maka pemerintah membentuk Badan Wakaf Indonesia (BWI) yaitu lembaga independen untuk mengembangkan perwakafan Indonesia di Provinsi atau Kabupaten/ Kota. (UURI Nomor 41 Tahun 2004).

Sutami (2012 : 15) menjelaskan, menurut data paling mutakhir yang dimiliki oleh Direktorat Pemberdayaan Wakaf Tahun 2011 berdasarkan laporan dari Kepala Bidang Haji, Zakat dan Wakaf. Kantor Wilayah Kementrian Agama Provinsi seluruh Indonesia, jumlah aset tanah wakaf Indonesia seluas 2.171.041.349, 74 M2, atau sekitar $2171 \mathrm{KM} 2$. Jumlah asset yang sedemikian luas dan tersebar di 414.848 lokasi di seluruh nusantara tersebut menunjukan besarnya potensi ekonomi wakaf. Kekayaan tersebut belum menghitung potensi wakaf uang yang sedang dan akan terkumpul sebagai salah satu jenis wakaf likuid yang telah diatur dalam peraturan perundang-undangan wakaf.

Hasil Penelitian Pusat Bahasa dan Budaya (PBB) UIN Syarif Hidayatullah Jakarta tahun 2006, terhadap 500 responden nazhir di 11 propinsi menunjukan bahwa $77 \%$ harta wakaf lebih banyak bersifat diam, sedangkan $23 \%$ lainnya produktif. Temuan umum lainnya juga menunjukan $79 \%$ pemanfaatan terbesar harta wakaf berupa bangunan masjid. Dari penelitian tersebut mayoritas pemanfaatan harta wakaf berupa bangunan masjid. Padahal dalam UU Nomor 41 Tahun 2004 Pasal 22 dijelaskan peruntukkan harta benda wakaf dialokasikan bagi sarana kegiatan ibadah, pendidikan, kesehatan, bantuan fakir miskin, anak terlantar, yatim piatu, beasiswa, kemajuan peningkatan ekonomi umat, dan kesejahteraan umum lainnya yang tidak bertentangan dengan 
syariah dan peraturan perundang-undangan. Sehingga sektor lain disamping pembangunan sarana kegiatan ibadah tidak teralokasikan dengan optimal dan hal itu menunjukan tidak akuntabel nya pengelolaan harta benda wakaf. (Aula, M.Abbas, 2006).

Melihat kondisi tersebut peneliti tertarik untuk meneliti model pengelolaan zakat dan wakaf produktif. Peneliti akan berusaha melihat bagaimanakah penerapan pengelolaan zakat dan wakaf produktif pada yayasan yatim mandiri cabang Malang. Kemudian dari penerapan pengelolaan zakat dan wakaf produktif tersebut permasalahan apa saja yang ada didalam pengelolaan zakat dan wakaf produktif pada yayasan yatim mandiri cabang Malang.

Hasil penelitian ini diharapkan dapat memberikan manfaat untuk memberikan gambaran lebih jauh kepada para ilmuwan, peneliti, pembaca dan masyarakat bahwa ada model pengelolaan wakaf hibah produktif yang bisa dijadikan contoh dalam pengelolaan zakat dan wakaf produktif. Selain itu sebagai bahan pertimbangan Pihak yayasan Yatim Mandiri di dalam mengembangkan pengelolaan zakat dan wakaf produktif itu sendiri.

Dalam penelitian ini penulis hanya fokus pada penerapan wakaf hibah produktif dan pemasalahan yang ada di yayasan yatim mandiri cabang malang saja. Dikarenakan ada perbedaan pengelolaan manajemen wakaf hibah produktif pada organisasi intitusi formal seperti badan wakaf Indonesia dengan yayasan.

\section{KAJIAN PUSTAKA}

\section{Wakaf $M u^{\prime} a b b a d$ dan Wakaf Muaqqat}

Secara umum, wakaf dibedakan menjadi dua : wakaf ahli (khusus) dan wakaf khayri (umum). Akan tetapi dalam perjalanannya, wakaf ahli (wakaf khusus untuk keluarga) tidak pernah diatur dalam perundang-undangan.

Salah satu mazhab fikih yang membicarakan dan membolehkan wakaf yang tidak muabbad adalah malikiah (mazhab fikih yang dinisbahkan kepada Imam Malik). Penganut mazhab ini berpendapat bahwa benda yang diwakafkan senantiasa milik wakif (sejalan dengan pendapat Abu Hanifah), dan wakaf boleh dilakukan dengan durasi (rentang waktu) tertentu, wakaf tidak mesti bersifat $m u^{\prime} a b b a d$ kecuali wakaf untuk masjid. Dalam mazhab ini, masjid disepakati adalah milik Allah. Oleh karena itu, 


\section{Analisa Model Pengelolaan Zakat dan Wakaf}

kepemilikan wakaf untuk masjid berpindah dari milik wakif menjadi milik umum. Hal ini berarti bahwa akad wakaf untuk masjid bersifat Mulazamah. (Zuhaili, 2006: 7602)

Regulasi Peraturan Perundangan Perwakafan

Sepanjang sejarah Islam, wakaf merupakan sarana dan modal yang amat penting dalam memajukan perkembangan agama. Sebelum lahir UU No.41 Tahun 2004 tentang wakaf, perwakafan di Indonesia diatur dalam PP No.28 Tahun 1977 tentang perwakafan tanah milik dan sedikit tercover dalam UU No.5 Tahun 1960 tentang peraturan dasar pokok Agraria. Namun, peraturan perundangan tersebut hanya mengatur benda-benda wakaf tidak bergerak dan peruntuannya lebih banyak untuk kepentingan ibadah besar seperti masjid, musholla, pesantren, kuburan, dll.

Keterbatasan cakupan peraturan perundangan perwakafan di regulasi sebelumnya, yang tidak mencakup diberdayakan dan dikembangkan wakaf secara lebih produktif maka regulasi diperbarui oleh pemerintah. Regulasi peraturan perundangan perwakafan tersebut berupa UU No.41 Tahun 2004 tentang wakaf dan Peraturan Pemerintah No.42 Tahun 2006 tentang pelaksanaannya. Kedua peraturan perundangan tersebut memiliki urgensi wakaf, yaitu selain untuk kepentingan ibadah besar, juga menekankan perlunya pemberdayaan wakaf secara produktif untuk kepentingan sosial.

Pengelolaan wakaf secara produktif untuk kesejahteraan masyarakat menjadi tuntutan yang tidak bisa dihindari lagi. Apalagi di saat Indonesia berkembang sedang mengalami krisis ekonomi yang memerlukan partisipasi banyak pihak. Oleh karena itu sudah selayaknya umat Islam khususnya, dan masyarakat Indonesia pada umumnya mengapresiasi peraturan perundangan perwakafan tersebut secara positif. Hadirnya regulasi tersebut merupakan penyempurnaan dari beberapa peraturan perundangan wakaf yang sudah ada sebelumnya dengan menambah hal-hal baru sebagai upaya pemberdayaan wakaf secara produktif dan profesional.

Setidaknya, peraturan perundangan perwakafan (UU dan PP wakaf) tersebut mememiliki substansi antara lain : pertama, benda yang diwakafkan (maukuf bih). UU dan PP wakaf ini mengatur juga benda wakaf yang bergerak, seperti uang, saham, surat-surat berharga lainnya dan hak intelektual. Tentu saja ini merupakan terobosan yang cukup signifikan dalam dunia 
perwakafan, karena wakaf seperti ini merupakan variabel penting dalam pengembangan ekonomi. Wakaf uang, saham atau surat berharga lainnya sebagaimana yang diatur dalam UU esensinya adalah agar wakaf ini yang diamanatkan kepada nadzir dapat dikelola secara produktif sehingga manfaatnya dapat digunakan untuk kepentingan kesejahteraan masyarakat banyak. Aspek kemanfaatan dzat (benda yang diwakafkan) menjadi esensi wakaf itu sendiri. Sehingga, dengan diaturnyta wakaf benda bergerak seperti uang, saham atau surat berharga lainnya diharapkan bisa menggerakkan seluruh potensi wakaf untuk kesejahteraan masyarakat luas.

Kedua, persyaratan nadzir. Ada beberapa hal yang diatur dalam UU dan PP wakaf mengenai nadzir wakaf, yaitu (a) selain perseorangan, terdapat penekanan berupa badan hukum dan organisasi seperti yayasan dan yang lainnya. Sehingga dengan menekankan bentuk badan hukum atau organisasi diharapakan dapat meningkatkan peran-peran kenadziran untuk mengelola wakaf secara lebih baik. (b) penambahan manajemen kenadziran secara profesional, seperti: amanah, memiliki pengetahuan mengenai wakaf, berpengalaman di bidang manajemen keuangan, kemampuan dan kecakapan yang diperlukan untuk menjalankan tugas nadzir. Penambahan persyaratan nadzir ini diharapkan dapat memaksimalkan pengembangan potensi wakaf yang ada. (c) Pembatasan masa jabatan nadzir dalam PP wakaf, ini menjadi poin penting agar nadzir bisa dipantau kinerjanya melalui tahap-tahap periodik untuk menghindari penyelewengan dan atau pengabaian tugas-tugas kenadziran. (d) Nadzir dapat menerima hak pengelola sebesar maksimal $10 \%$ dari hasil bersih pengelolaan dan pengembangan benda wakaf, agar nadzir wkaf tidak sekedar dijadikan pekerjaan sambilan yang hanya dijalani seadanya, tapi benar-benar mau dan mampu menjalankan tugas-tugasnya sehingga mereka patut diberikan hak-hak yang pantas sebagaimana mereka kerja di dalam dunia profesional.

Ketiga,menekankan pentingnya pembentukan sebuah lembaga wakaf nasional yang disebut dengan Badan Wakaf Indonesia (BWI). Badan wakaf ini bersifat independen yang bertujuan unuk membina terhadap nadzir dalam mengelola dan mengembangkan harta benda wakaf baik secar nasional maupun nterasional. Sehingga BWI kelak akan menduduki peran kunci, selain berfungsi sebagai nadzir juga berfungsi sebagai pembina 


\section{Analisa Model Pengelolaan Zakat dan Wakaf}

nadzir sehingga harta benda wakaf dapat dikelola dan dikembangkan secara produktif.

Keempat, menekankan pentingnya pemberdayaan harta benda wakaf yang menjadi ciri utama Uudan PP wakaf ini. Aspek pemberdayaan dn pengembngan benda wakaf selam ini memang terlihat belum optimal karena disebabkan oleh banyak hal antara lain pahan konservatisme umat Islam mengenai wakaf, khususnya yang terkait dengan harta benda wakaf tidak bergerak. UU dan PP wakaf ini menekankan pentingya pemberdayaan danpengembangan benda-benda wakaf yang mempunyai potensi ekonomi tinggi untuk kesejahteraan masyarakat banyak.

Kelima, catatan penting dalam UU dan PP ini adalah adanya ketentuan pidana sanksi administrasi. Ketentuan pidana yang dimaksud ditujukan kepada para pihak yang dengan sengaja menyalahgunakan benda wakaf dengan ancaman pidana penjara paling lama 5 tahun dan atau pidana denda paling banyak Rp. $500.000 .000,-$. Sedangkan bagi pihak yang dengan sengaja mengubah peruntukan benda wakaf akan dipidana penjara paling lama 4 tahun dan atau pidana denda paling banyak Rp. 400.000.000,-. Sedangkan sanksi administrasi akan dikenakan kepada lembaga keuangan syariah dan pejabat pembuat aka ikrar wakaf (PEAIW) yang melanggar dalam masalah pendaftaran benda wakaf. Ketentuan pidana dan sanksi administrasi ini merupakan terobosan yang cukup penting dalam rangka mengamankan benda-benda wakaf dari tangan-tangan yang tidak bertanggungjawab dan bertujuan untuk memberikan aspek jera agi mereka yang telah melakukan pelanggaran hukum.

Sedangkan dalam realitanya menunjukkan bahwa sebagian besar lembaga wakaf memakai format yayasan yang lebih bernuansakan sosial dan nirlaba, daripada komersial. Untuk keperluan ini sesungguhnya dapat dipakai pendekatan akuntansi dana. Selanjutnya, bila wakaf akan dikelola secara lebih produktif dalam bentuk usaha komersial misalnya, maka dapat dipakai akuntansi konvensional. Namun perlu dicatat bahwa sejumlah permasalahan dalam akuntansi konvensional, baik karena sifat bawaannya maupun bila dilihat dari perspektif Islam. Oleh karena itu, diperlukan segera upaya untuk melakukan penyempurnaan agar bagian-bagian yang dipandang tidak Islami, dapat dikurangi atau kalau dapat dieliminasi. Sesungguhnya akuntansi hanya sebatas alat, sedapatnya juga bersifat Islami. prinsip yang sama juga berlaku bagi sistem auditing. 


\section{METODE PENELITIAN}

Jenis penelitian ini adalah kualitatif dengan pendekatan deskriptif. Penelitian kualitatif didefinisikan oleh Bogdan \& Taylor (1975:5) dalam Moleong (2006:4) adalah sebagai prosedur penelitian yang menghasilkan data deskriptif berupa kata-kata tertulis atau lisan dari orang-orang dan perilaku yang dapat diamati. Dalam penelitian ini peneliti mendeskripsikan tentang penerapan pengelolaan zakat dan wakaf produktif pada yayasan yatim mandiri cabang Malang. Dan menurut Supardi (2005:28), penelitian deskripsi secara garis besar merupakan kegiatan penelitian yang hendak membuat gambaran atau mencoba mencandra suatu peristiwa atau gejala secara sistematis, faktual dengan penyusunan yang akurat.

\section{HASIL DAN PEMBAHASAN}

Profil Yayasan Yatim Mandiri Malang

Yatim Mandiri merupakan lembaga nirlaba yang fokus pada upaya memandirikan anak yatim dan dhuafa melalui pengelolaan dana zakat, infaq, sedekah, wakaf dan lainnya. Berawal dari kegelisahan beberapa orang aktivis panti asuhan di Surabaya yaitu Sahid Has, Sumarno, Hasan Sadeli,Syarif Mukhodam dan Moch Hasyim yang melihat anak-anak yatim yang lulus SMA dipanti asuhan. Karena tidak semua Panti Asuhan mampu untuk menyekolahkan para anak binaan samapai ke Perguruan Tinggi atau mampu mencarikan mereka lapangan pekerjaan jadi sebagian besar anak-anak yatim ini dipulangkan kembali kepada orangtuanya yang masih ada. Setelah mereka pulang kembali maka hidup mereka akan kembali seperti semula. Melihat kondisi seperti ini, mereka berpikir bagaimana anak-anak ini bisa hidup mandiri tanpa bergantung lagi kepada orang lain.

Kemudian mereka merancang sebuah Yayasan yang bergerak dalam pendidikan anak yatim purna asuh dari panti asuhan dengan program mengikutsertakan anak-anak yatim kursus keterampilan.Yayasan ini berjalan dengan baik dan potensi anak yatim yang harus dimandirikan juga cukup banyak. Maka untuk mewujudkan mimpi memandirikan anak-anak yatim itu maka pada tanggal 31 Maret 1994 dibentuklah sebuah yayasan yang diberi namaYayasan Pembinaan dan Pengembangan Panti Asuhan Islam dan Anak Purna Asuh (YP3IS). Kemudian tanggal tersebut dijadikan sebagai hari lahir. 


\section{Analisa Model Pengelolaan Zakat dan Wakaf}

Dalam perjalanannya selama 14 tahun berbagai catatan perjalanaan telah terhimpun.Baik yang berkaitan dengan legalitas maupun operasional kesehariannya. Di antaranya sesuai dengan undang-undang nomor 16 tahun 2000 tentang yayasan batas toleransi penyesuaiannya adalah tahun 2005, sehingga demi kepentingan public yayasan harus melakukan pendaftaran ke Depkumham pusat di Jakarta ternyata Depkumham menolak karena nama YP31S telah digunakan oleh pihak lain. Catatan yang lain, nama YP3IS terlalu panjang dan kurang bisa memberikan fungsi branding yang marketable dalam pengembangan publikasi Lembaga kemasyarakat. YP3IS semakin berkembang dengan baik berkat dukungan dana dari masyarakat dan semakin profesional untuk memandirikan anak yatim melalui program-programnya. Setelah melalui banyak perubahan baik secara kepengurusan maupun secara manajemen dan untuk memperluas kemanfaatan memandirikan anak yatim maka melalui rapat, diputuskan untuk mengganti nama menjadi Yatim Mandiri. Pada tanggal 22 Juli 2008 Yatim Mandiri terdaftar di Depkumham dengan nomor: AHU2413.AH.01.02.2008. Dengan nama baru Yatim Mandiri diharapkan akan menjadi lembaga pemberdaya anak yatim yang kuat di negeri ini. Sampai tahun 2014 ini saat usia Yatim Mandiri sudah memiliki 40 kantor Cabang di 12 Propinsi di Indonesia. Hal ini mencangkup beberapa daerah kota besar, yakni saat ini Yayasan Yatim Mandiri telah hadir di 11 jaringan kantor kota besar di Jawa Timur dan Jawa Tengah.. Kota besar yang sudah terdapat kantor operasional Yayasan Yatim Mandiri antara lain, Surabaya, Sidoarjo, Gresik, Malang, Kediri, Jember, Tuban, Pasuruan, Semarang, Mojokerto dan Madiun.

Untuk Yatim mandiri yang ada di Malang sendiri berdiri pada tahun 2007, dan sudah beroperasi kurang lebih sembilan tahun hingga saat ini serta memiliki dua kantor yang beralamat di Kepanjen dan Blimbing. Dengan berbagai program kemandirian yang ada, harapannya Yatim Mandiri di seluruh Indonesia semakin berkembang lebih baik dan mampu menebar manfaat lebih luas. Sedangkan sebagai bentuk profesionalitas dan keamanahan, Yayasan Yatim Mandiri mengembangkan Lembaga Pusat Pendidikan dan Pelatihan (PUSDIKLAT) yang peruntukannya khusus untuk anak-anak yatim purna asuh (anak lulus SMU) dengan biaya GRATIS / Nol rupiah. Lembaga pusdiklat yatim ini bernama MEC (Mandiri Enterpreneur Center) 
yang mempunyai visi dan misi untuk mencetak jiwa-jiwa interpreneur pada diri anak-anak yatim binaannya.

Tabel 2 Program Yayasan Yatim Mandiri

\begin{tabular}{|c|c|c|}
\hline $\begin{array}{c}\text { Nama } \\
\text { Program } \\
\end{array}$ & $\begin{array}{c}\text { Macam-macam } \\
\text { Program } \\
\end{array}$ & Keterangan \\
\hline 1) Pendidikan & 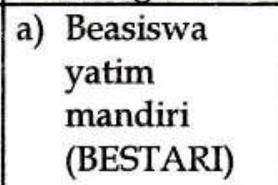 & $\begin{array}{l}\text { Program beasiswa pendidikan bagi } \\
\text { anak-anak yatim usia SD, SMP, dan } \\
\text { SMA }\end{array}$ \\
\hline & $\begin{array}{l}\text { b) Insan } \\
\text { Cendekia } \\
\text { Mandiri } \\
\text { (ICM) }\end{array}$ & $\begin{array}{l}\text { Program ini diperuntukan untuk } \\
\text { anak-anak yatim berprestasi tingkat } \\
\text { SMP dan SMA, yang } \\
\text { menitikberatan pada pembinaan ke- } \\
\text { islaman, kepemimpinan dan } \\
\text { prestasi akademik siswa }\end{array}$ \\
\hline & $\begin{array}{l}\text { c) Mandiri } \\
\text { entrepreneur } \\
\text { Center }\end{array}$ & $\begin{array}{l}\text { Program pelatihan Vokasi untuk } \\
\text { anak-anak yatim lulusan SMA atau } \\
\text { sederajat bertujuan untuk } \\
\text { memberikan keterampilandan } \\
\text { pengetahuan khusus, guna } \\
\text { mencetak tenaga ahli yang } \\
\text { profesional dan menjadi wirausaha } \\
\text { mandiri di bidangnya. }\end{array}$ \\
\hline & $\begin{array}{l}\text { d) Rumah } \\
\text { Kemandirian }\end{array}$ & $\begin{array}{l}\text { Model pemberdayaan anak yatim } \\
\text { berbasis ICD (Integrated } \\
\text { Community Development) }\end{array}$ \\
\hline 2) Kesehatan & $\begin{array}{l}\text { a) Layanan } \\
\text { kesehatn } \\
\text { keliling dan } \\
\text { mobil sehat }\end{array}$ & $\begin{array}{l}\text { Layanan kesehatan meliputi: } \\
\text { pemeriksaan kesehatan rutin, } \\
\text { pemeriksaan kesehatan gigi, } \\
\text { pengobatan gratis dan penambahan } \\
\text { gizi bagi anak yatim }\end{array}$ \\
\hline & $\begin{array}{l}\text { b) Rumah sehat } \\
\text { mandiri }\end{array}$ & $\begin{array}{l}\text { Program klinik kesehatan mandiri } \\
\text { yang melayani pasien dan keluarga } \\
\text { yatim dhuafa, masyarakat yang } \\
\text { kurang mampu dengan tujuan } \\
\text { untuk meringanan mereka. } \\
\text { Layanannya meliputi: pemeriksaan } \\
\text { dasar umum (gigi dan umum), } \\
\text { laboratorium dasar serta pemberian } \\
\text { gizi bagi anak yatim }\end{array}$ \\
\hline & c) Gizi & $\begin{array}{l}\text { Program pemberian makanan } \\
\text { tambahan bagi anaak-anaak yaatim }\end{array}$ \\
\hline
\end{tabular}


Analisa Model Pengelolaan Zakat dan Wakaf

\begin{tabular}{|c|c|c|c|c|}
\hline & & & & dhuafa guna peningkatan gizi \\
\hline 3) & Ekonomi & & Bunda yatim & $\begin{array}{l}\text { Program pendampingan bunda } \\
\text { yatim dalam bidang peningkatan } \\
\text { ekonomi keluarga dan rohani }\end{array}$ \\
\hline 4) & $\begin{array}{l}\text { Sosial } \\
\text { Kemanusiaa } \\
\mathrm{n}\end{array}$ & a) & $\begin{array}{l}\text { Bantuan } \\
\text { bencana } \\
\text { alam }\end{array}$ & $\begin{array}{l}\text { Program bantuan kemanusiaan } \\
\text { yang diberikan kepada korban } \\
\text { bencana alam yang terjadi. Baik } \\
\text { pada saat tanggap bencana maupun } \\
\text { recovery }\end{array}$ \\
\hline & & b) & $\begin{array}{l}\text { Bantuuan } \\
\text { lansung } \\
\text { mustahiq }\end{array}$ & $\begin{array}{l}\text { Bentuk bantuan kepedulian yatim } \\
\text { mandiri untuk membantu } \\
\text { mustahiq. Program ini diberkan } \\
\text { secara insidentil kepada mustahiq } \\
\text { yang bersifat urgent dan berfokus } \\
\text { pada bidang pendidikan, kesehatan, } \\
\text { dan ekonomi. }\end{array}$ \\
\hline 5) & $\begin{array}{l}\text { Program } \\
\text { Khusus }\end{array}$ & a) & $\begin{array}{l}\text { Program } \\
\text { Ramadhan }\end{array}$ & $\begin{array}{l}\text { Buka puasa ceria, Al-Quran Yatim } \\
\text { nusantara dan Bercahya (Berbagi } \\
\text { Ceria di Hari Raya) }\end{array}$ \\
\hline & & & $\begin{array}{l}\text { Super Gizi } \\
\text { Qurban }\end{array}$ & $\begin{array}{l}\text { Program yang didesain untuk } \\
\text { menyempurnakan daging qurban } \\
\text { dalam bentuk sosis }\end{array}$ \\
\hline & Dakwah & & $\begin{array}{l}\text { Kursus baca } \\
\text { Quran }\end{array}$ & $\begin{array}{l}\text { Sebuah layanan gratis dengan } \\
\text { memberikan pelajaran kepaada } \\
\text { donator cara membaca Al-Quran } \\
\text { secara baik dan benar (tartil) }\end{array}$ \\
\hline & & b) & $\begin{array}{l}\text { Layanan } \\
\text { Ceramah } \\
\text { Gratis }\end{array}$ & $\begin{array}{l}\text { Sebuah layanan gratis yang } \\
\text { mencoba menawarkan kegiatan } \\
\text { pengajian karyawan di peruahan- } \\
\text { perusahan donator }\end{array}$ \\
\hline & & & $\begin{array}{l}\text { Mobil } \\
\text { jenazah }\end{array}$ & $\begin{array}{l}\text { Merupakan program memberikan } \\
\text { layanan khusus untuk mengantar } \\
\text { jenazah kepada masyarakat yang } \\
\text { membutuhkan secara gratis }\end{array}$ \\
\hline
\end{tabular}

\section{Sumber Daya Manusia (Amil zakat)}

Yatim mandiri malang memiliki karyawan sebanyak 18 orang yang terdiri atas kepala cabang, staf keuangan, staf marketing zisco (penghimpun), staf penyaluran, staf data dan staf program. Dengan rata-rata karyawan lulusan Strata-1 bahkan ada juga yang lulusan SMA.

Dalam hal ini Yatim Mandiri juga sangat memerhatikan indikator dalam perekrutan karyawan yang mana mengutamakan 
orang-orang yang memiliki kemampuan spiritual agama dan intelektual yang baik.

\section{Sistem Organisasi dalam Pengelolaan Zakat dan Wakaf}

Dalam lembaga YayasanYatim Mandiri memiliki sistem organisasi independen, yang dimana bentuk lembaganya seperti Lembaga Amil Zakat pada umumnya sehingga dalam sistem organisasinya tidak ada campur tangan dari peraturan pemerintah. Dan struktur organisasi Lembaga Yatim Mandiri sendiri secara umumnya antara lain pembina, pengawas, pengurus, dewan penasehat, dewan pengawas syariah, direktur, direktur operasional, direktur LAZ, direktur LPP

Lembaga Yatim Mandiri Malang terdiri atas beberapa struktur didalamnya seperti ketua cabang, program/kepala bidang, Bagian Keuangan dan staf penerima.

\section{Legalitas Yayasan Yatim Mandiri Malang}

Yayasan Yatim Mandiri merupakan yayasan yang sudah lama berdiri dan dipercaya masyarakat. Adapun legalitas yayasan yatim mandiri yaitu:

a. Dicatatkan dinotaris Triningsih Ariswati, $\mathrm{SH}$.

b. Surat Keterangan Domisili “745/40/436.11.23.1/2013”.

c. Berdasarkan keputusan MENKUMHAM RI AHU2431.AH.01.02.2008.

d. Perubahan akta yayasan Maya Ekasari Budiningsih, SH. No. 12 tahun 2008.

e. Perubahan pengurus yayasan akte notaris Habib Adjie, $\mathrm{SH}$., M.Hum. No. 5 Tahun 2014.

f. NPWP 02.840.224.6-609.000

\section{PERMASALAHAN YANG ADA DAN SOLUSINYA}

Kendala-kendala / Permasalahan yang di alami di Yayasan Yatim Mandiri Malang

Menurut hasil observasi dan wawancara yang kami lakukan pada Yayasan Yatim Mandiri Malang ada beberapa kendala dalam penyaluran dana dan pengelolaan sumber daya manusia baik dari sisi eksternal maupun internal, seperti:

Masalah Internal:

1. Minimnya Sumber Daya Manusia yang berkualitas

Dalam pengelolaan zakat dan wakaf, disini sangat minim orang yang handal dan berkualitas baik dalam hal pengelolaan 
lembaga amil zakat dan wakaf, akuntansi,transparan, amanah dan profesional. Pada zaman sekarang banyak sekali orang ekonom yang tidak mau terjun kedalam lembaga amil zakat dan wakaf karna kebanyakan dari mereka lebih memilih karir yang jelas dan lebih memilih pendapatan yang jelas. Disini untuk menjadi amil zakat dan wakaf belum memiliki pendapatan yang jelas sehingga belum bisa memberikan ketertarikan khusus kepada sarjanasarjana dan masyarakat lain yang memiliki kualitas yang baik.

Banyak para amil terutama yang masih bersifat tradisional, mereka sangat kaku memahami fiqih, sehingga tujuan utama zakat tidak tercapai. Masih minimnya pemahaman fikih zakat wakaf dari para amil masih menjadi salah satu hambatan dalam pengelolaan zakat dan wakaf.

Yang menjadi masalahnya juga yakni susahnya mendapatkan sumber daya yang berkualitas, yang di maksud adalah susahnya dari yatim mandiri mendapatkan sumber daya manusia yang berpendidikan, yang benar-benar faham dengan zakat dan wakaf serta bisa memajukan yatim mandiri sehingga dari administrasi dan kinerjanya menjadi maksimal

2. Kemampuan Sumber Daya Manusia yang kurang kreatif

Pada kegiatan penyaluran dana biasanya dari pihak Yatim Mandiri Malang sendiri sering melakukan event-event untuk menarik animo masyarakat supaya datang dan menyaksiskan acara tersebut.

Dalam hal ini kreatifitas karyawan Yayasan Yatim Mandiri sangat dibutuhkan Untuk strategi penghimpunan danadan pada kenyataannya kreatifitas karyawan tersebut sejauh ini belum bisa membikis event-event tersebut dengan baik sehingga animo masyarakat untuk menyalurkan sebagian hartanya untuk ZISWAF ke Yayasan Yatim Mandiri sangat kurang.

\section{Masalah Eksternal:}

1. Pemikiran masyarakat masih sederhana

Sudah melekat dalam sebahagian kaum muslim bahwa perintah zakat itu hanya diwajibkan pada bulan Ramadhan saja itupun masih terbatas pada pembayaran zakat fitrah. Padahal zakat bukanlah sekedar ibadah yang diterapkan pada bulan Ramadhan semata, melainkan juga dapat dibayarkan pada bulanbulan selain Ramadhan. Sehingga ide dasar zakat untuk kemaslahatan umat telah bergeser menjadi sekedar ibadah ritual semata yang dikerjakan bersamaan dengan ibadah puasa. 
Pemikira di masyarakat masih sangat sederhana, dimana uang ataaupu harta yang dimiliki untuk mengeluarka zakat tidak perlu melalui lembaga amil zakat, tetapi langsung diberikan kepada orang membutuhkan langsung sehingga untuk lembaga amil zakat disini belum di maksimalkan karna pemikirannya masih sederhana dan langsung berfikir bahwasanya langsung di berikan kepada orangnya langsung lebih jelas.

Begitupun wakaf, disini banyak orang yang belum memahami tentang kesadaran pada wakaf itu sendiri. Karena dalam wakaf sebenarnya pemahaman saat ini kebanyakan untuk hal ibadah saja seperti masjid, sekolah. Namun, wakaf juga dapat berbentuk uang, tanah dan bangunan dan bisa disalurkan pada sekolah-sekolah maupun pembiayaan pengembangan pemberdayaan masyarakat.

2. Kurangnya dukungan dari keluarga

Masyarakat banyak yang berfikir dan bertanya-tanya dari mana uang tersebut, masih banyaknya masyarakat yang masih belum percaya dengan amil zakat dan juga banyaknya kecurigaan dari masyarakat, bahkan bayak yang berfikiran negatif karna dikiranya dalam penyaluranya dari yatim mandiri janga-jangan memiliki tujuan tertentu yang aka berdampak negatif bagi si penerima.

Dan dalam penyaluran untuk sekolah juga dari yatim mandiri masih kesusahan, baik itu dari anaknya yag tidak mau karna terlalu jauh ataupun dari orang tua sendiri yang tidak mau di tinggal oleh anaknya atau jauh dari anaknya.

\section{SOLUSI}

1. Sumber Daya Manusia yang Berkualitas (Internal)

Jadi dari semua ini harus lebih memaksimalkan sumber daya manusia yang ada, sehigga dalam pengolahan yag ada lebih efektif, baik dari pemahaman tentag fiqih ziswaf maupu kinerja dari sumberdayanya sendiri. Yang lebih faham tentang pegelolaan ziswaf, akuntan, transparan amanah dan profesional. Dan bisa juga melalui pelatihan ataupun pemahaman kepada sumberdaya manusia untuk menjadi pengelola yang lebih berkualitas dengan pertemuan dengan amil zakat yang lain. Dan bahkan sering dari yatim mandiri mengundang dose ui malang untuk menjelaskan dan memahamkan pemahaman.

2. Pemaksimalan marketing (Eksternal) 


\section{Analisa Model Pengelolaan Zakat dan Wakaf}

Disini menurut yatim madiri kunci dari yatim mandiri ataupun ujug tombaknya adalah dari marketing, dimana harus banyak-banyak mencari donatur sebanyak-banyaknya. Sehingga dari pemaksimalan marketing mejadikan penggait donatur sebanyak banyakya. Dan apabila pemberi dana banyak pasti dari berjalannya yatim mandiri akan lancar.

3. Memberikan pemahaman kepada keluarganya anak yatim (Eksternal)

Dengan memberikan pemahaman dan prosek yang jelaas kepada si anak yatim tersebut dirasa mampu untuk memengaruhi keluarganya sehingga pihak kelarganya sendiri rela untuk melepas anaknya untuk mondok/sekolah di yayasan yatim mandiri

Menurut hasil wawancara dari Bapak Imam, Dana yang dikelola yayasan Yatim Mandiri dari zakat kurang banyak yakni sekitar $10 \%$ dari semua dana yang terkumpul dan $90 \%$ lainnya adalah dana hasil sedekah, infak, dan dana keagamaan lainnya. Dana yang terkumpul tahun 2015 berjumlah lebih dari 56 milyar. Dana ini digunakan $10-12 \%$ untuk operasional dan lainnya disalurkan pada tiap-tiap program. Menuru MUI dana operasional itu diambil dari dua asnaf yaitu amilin dan sabilillah. Seperti untuk membiayai seluruh jajaran karyawan di Yatim Mandiri diambil dari peruntukan amilin sekitar $10-12 \%$ dan untuk membuat majalah. Brosur diambilkan dari peruntukan sabilillah.

Penyaluran zakat tidak saja digunakan untuk kebutuhan konsumtif, tetapi juga untuk kebutuhan produktif, sehingga zakat menjadi salah satu institusi ekonomi umat dengan pengembangan usaha-usaha produktif umat Islam. Penyaluran dan pendayagunaan dana untuk keperluan produktif bisa diberikan dalam bentuk bantuan modal kepada mereka yang masih mempunyai kemampuan bekerja dan berusaha. Tentunya, disertai pula dengan dukungan teknik dan manajemen bagi kaum ekonomi lemah, sehingga mereka bisa mandiri dan terlepas dari kemiskinan. Dengan demikian, kita tidak lagi memberikan ikan, tetapi memberikan pancing, diharapkan pada tahun tahun berikutnya mustahik tadi tidak lagi sebagai penerima zakat tetapi telah berubah nasib menjadi pembayar zakat (muzaki).

Pelaporan

Aspek pelaporan dilakukan dengan transparan dan jelas harus dilakukan untuk menimbulkan kepercayaan dan ketenangan hati para muzakki.Laporan dilakukan setiap periode. Periode itu setiap bulan sekali laporan secara global dan setiap tahun 
dilakukan audit eksternal. Sistem laporan di yayasan Yatim Mandiri berdasarkan sistem laporan PSAK No. 109 tentang Akuntansi Pengelolaan Zakat.

Yayasan Yatim Mandiri melaporkan hasil keuangan dan kinerjanya kepada masyarakat khususnnya kepada donatur melalui majalah bulanan, brosur, dan koran republika. Berikut laporan dana bulan Desember 2015:1

Tabel 4. Laporan Penerimaan dan Penyaluran Dana LAZ Yayasan Yatim Mandiri Bulan Desember 2015

\begin{tabular}{|r|r|}
\hline \multicolumn{2}{|c|}{ LAZ-YAYASAN YATIM MANDIRI } \\
LAPORAN PENERIMAAN DAN PENYALURAN DANA BULAN \\
DESEMBER 2015 (Dalam Rupiah) \\
\hline PENERIMAAN \\
\hline 1. Penerimaan Dana Zakat \\
\hline 2. .Penerimaan Dana Infak Shodakoh \\
\hline 3. Penerimaan Dana Terikat & $541,412,191$ \\
\hline Total Penerimaan & $4411,988,229$ \\
\hline Surplus Bulan Lalu & $6,601,928,666$ \\
\hline Dana Tersedia & $3,300,744,782$ \\
\hline PENYALURAN & $9,902,673,448$ \\
\hline 1. Program Sekolah SMP ICMBS \\
\hline 2. Program Kuliah MEC \\
\hline 3. Program Pendukung & $3,015,408,525$ \\
\hline a) Beasiswa Operasional Pendidikan & $392,960,111$ \\
\hline b) Beasiswa Guru Panti & $154,173,529$ \\
\hline c) Beasiswa Guru Genius & $102,516,150$ \\
\hline d) Program Rumah Kemandirian & $168,851,353$ \\
\hline e) Program Kesehatan dan Gizi & $36,826,834$ \\
\hline f) Muharram & $36,955,206$ \\
\hline g) Supercamp & 762,600 \\
\hline
\end{tabular}

${ }^{1}$ Ibid, Majalah Yatim Mandiri, (Maret, 2016),29. 
Analisa Model Pengelolaan Zakat dan Wakaf

\begin{tabular}{|r|r|}
\hline h) Kemanusiaan & $22,670,700$ \\
\hline i) Super Gizi Qurban & $174,799,000$ \\
\hline j) Klinik & $33,248,132$ \\
\hline $4 . \quad$ Dakwah & $1,108,959,311$ \\
\hline $5 . \quad$ Amil dan Admin & $693,086,836$ \\
\hline $6 . \quad$ Inventaris & $5,400,000$ \\
\hline JUMLAH PENYALURAN & $6,085,853,383$ \\
\hline SURPLUS BULAN INI & $3,816,820,065$ \\
\hline
\end{tabular}

MODEL MANAJEMEN ZAKAT DAN WAKAF PRODUKTIF

Dari pembahasan diatas dapat dibuat model pengelolaan manajemen dan administrasi modern untuk zakat dan wakaf produktis sebagaiman gambar di bawah ini :

Gambar 1. Model pengelolaan zakat dan wakaf
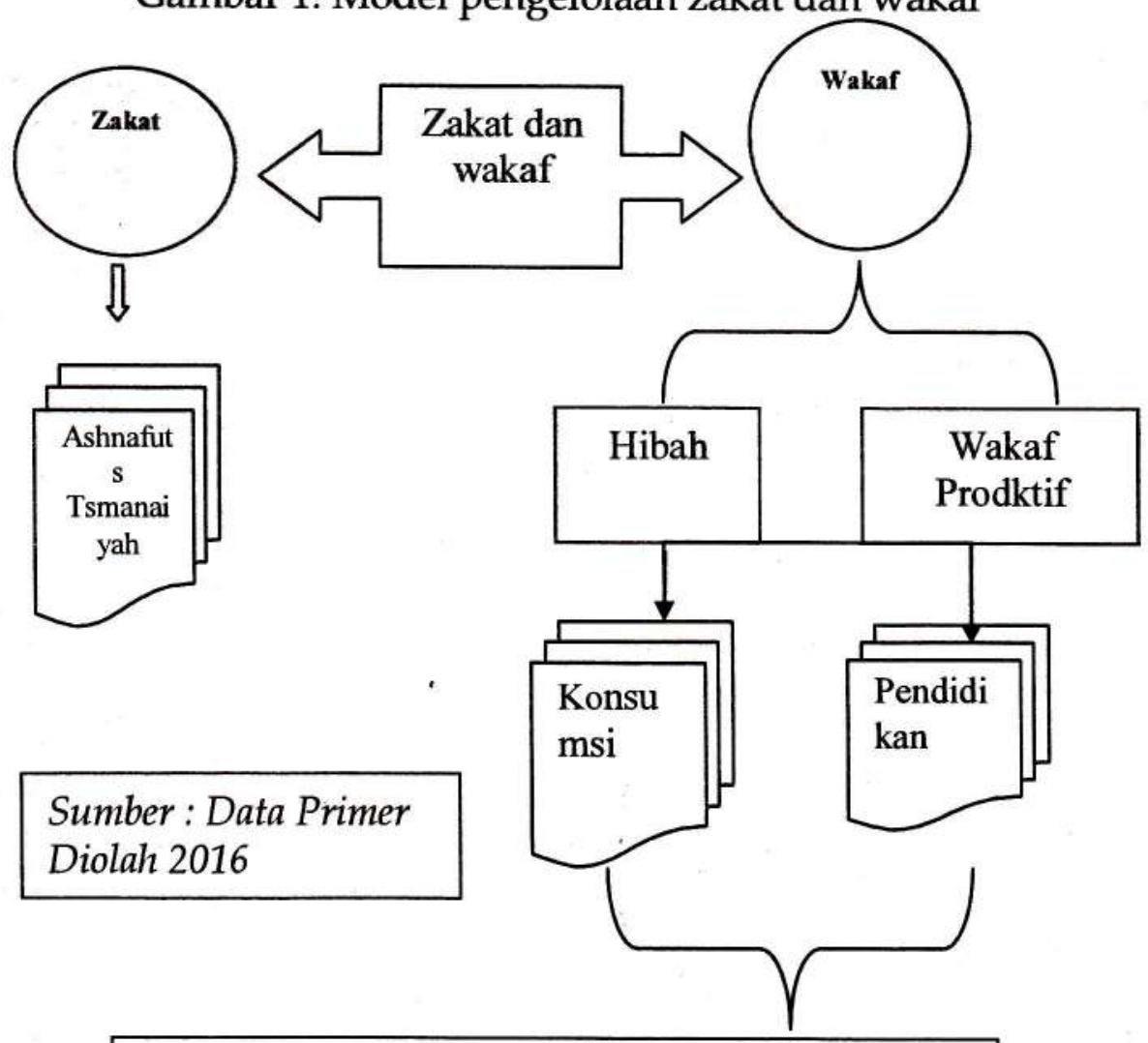

KEGUNAANYA UNTUK MEMENUHI KEBUTUHAN

SANTRI YATIM

El-Dinar, Vol. 4, No. 2, Juli 2016 


\section{KESIMPULAN DAN SARAN}

Berdasarkan pembahasan diatas dapat disimpulkan bahwa: Dalam lembaga Yayasan Yatim Mandiri memiliki sistem organisasi independen, yang dimana bentuk lembaganya seperti Lembaga Amil Zakat pada umumnya sehingga dalam sistem organisasinya tidak ada campur tangan dari peraturan pemerintah.

Kendala-kendala / Permasalahan yang di alami di Yayasan Yatim Mandiri Malang dari aspek internal adalah Minimnya Sumber Daya Manusia yang berkualitas dan Kemampuan Sumber Daya Manusia yang kurang kreatif. Kendala-kendala /permasalahan yang dihadapi di Yayasan Yatim mandiri Malang dari aspeks eksternal adalah Pemikiran masyarakat masih sederhana Kurangnya dukungan dari keluarga.

Untuk menyelesaikan permasalahan internal yayasan yatim mandiri tersebut adalaah dengan menyiapkanSumber Daya Manusia yang Berkualitas (Internal). Sedangkan untuk permaslahan eksternal maka hendaknya memaksimalkan marketing dan Memberikan pemahaman kepada keluarganya anak yatim

\section{DAFTAR PUST AKA}

Aula, Muhammad Abbas. (2012). "Pemberdayaan Umat Melalui

Lembaga Wakaf". Jurnal Wakaf dan Ekonomi Islam Vol. V, Nomor 2, Juli 2012

Barohima, Anwar.2008. Kedudukan Yayasan di Indonesia: Eksistensi, tujuan, dan tanggungjawab Yayasan. Jakarta: KENCANA

Fakhruddin.2008.Figh dan Manajemen Zakat di Indonesia.Malang: UIN Pres grahasedekah.ilmifoundation.or.id

Ismawati, 2007, Penyelesaian Sengketa Tanah Wakaf; Studi

Terhadap Tanah Wakaf Banda Masjid Agung Semarang, tesis

tidak dipublikasikan, Program Studi Kenotariatan, Program Pascasarjana Undip.

Moleong, L.2006.Metodologi Penelitian Kualitatif ,Edisi Revisi. Bandung: Penerbit Remaja Rosdakarya

Nurhayati, Sri.2015.Akuntansi Syariah di Indonesia Edisi 4.Jakarta: Salemba Empat

Nawawi, Ismail.2010.Zakat- Dalam Perspektif Figh, Sosial, dan Ekonomi.Surabaya: Putra Media Nusantara

Sudarsono, Heri. 2008.Bank Lembaga Keuangan Syariah : Deskripsi dan Ilustrasi, Ekonisia, Yogyakarta 
Analisa Model Pengelolaan Zakat dan Wakaf

Supardi.2005.Metodologi Penelitian Ekonomi dan Bisnis, Edisi Pertama. Yogyakarta: Penerbit UII Press

Sutami. (2012). "Perkembangan Wakaf Produktif di Indonesia". Jurnal Wakaf dan Ekonomi Islam Vol. V, Nomor 2, Juli 2012.

Tulus. 2003. Pedoman pengelolaan dan pengembangan wakaf. Jakarta: Direktorat Jendral Bimbingan Masyarakat Islam

Zuhaili, Wahbah, al-2006. Al Figh al-Islami wa Adillatuh. Damaskus: Dar al-Fik 